\title{
XXII. Observations on the purity of standard gold
}

\section{Fabbroni}

To cite this article: M. Fabbroni (1810) XXII. Observations on the purity of standard gold, Philosophical Magazine Series 1, 36:148, 132-141, DOI: 10.1080/14786441008563153

To link to this article: http://dx.doi.org/10.1080/14786441008563153

$$
\text { 册 Published online: } 18 \text { May } 2009 .
$$

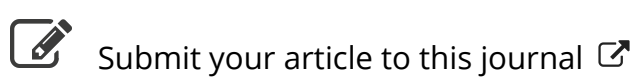

LII Article views: 3

Q View related articles $\asymp$ 


\section{[ 132$]$}

XXII. Olservations on the Purity of Standard Gold. By. M. FabBroni, of Florence, corresponding Memler of the French Institute. To which are suljoined Notes by M. D'Arcet, Assay Master of the French Mint*.

Armost all naturalists (following perhaps implicitly the assertion of Pliny $\dagger$ ) maintain that native gold is never found pure; i.e. entirely free from alloy, chiefly of silver, and that the finest is scarcely from 0.875 to 0.917 , or 21 or 22 carats. The gold in dust, in spangles, or in sand, which is brought from Africa, is most frequently within these limits. I have seen snme gold from the country of Bambuck in Africa, which was 0.927 , or 22 carats and onefourth; in the mint of Florence it has also been seen at $\mathbf{0 . 9 5 8}$, or 23 carats : this gold had been brought from Morocco. The carat in Tuscany is divided into eighths.

It is probable that in the early ages money was coined with naive gold, in the state in which it was found, there being no grounds for supposing that they took pains to refine it.

It has been thought that the oldest gold enin know $n$ is that of Battus IV, which was melted or struck at Cyrene in Africa in the time of Pisisiratus: it does not appear that the standard of this gold was known. Of all the Grecian coins which are in the hands of the collectors of medals, the most ancient are the beautiful pieces of Philip the father of Alexander. That enterprising man, who from his infancy conceived the idea of ascending the throne of Macedon, and becoming master of Greece, was fortunate enough to find several rich mines of gold, which he knew how to prize. Mount Pangea annually furnisbed him with gold to the amount of $5,829,000$ francs, and from thence he derived the most powerful rescurces for the success of his political designs and military talents. It is not known whether this metal of Philip's underwent any particular operations before passing to the mint. There are some

* Anuales de Chimie, tone Ixxii. p. 25.

+ Pliny says, lib. s3, thist there is co kind af gold more perfect than spangle gold; that gold obined by searching the beds of rivers does not require melting, ard that it is native and perfect gold. But Pliny says in the same book that lead is more malleable and heavier than gold; which proves that the gold which he regarded as pure was in reality an alloy. He says likewise a little further on, i hat all goid is mixed with silver, and that the gold whirh is the least alloyed with silver came from Albicratum in Caul, and that it coitained only $\frac{1}{30}$. From all this it is evident that Pliny's opinion is not to be followed, and recourse must be had to experiments.

grounds, 
grounds, however, for thirking that it was used in the state in which it was found.

Patin assaved a statera of gold of this king (the denomination of his coin among the Persians and Macedonians), and found it to be 23 carats and a half, or 0.970 . We cannot allow ourselves to believe that the metallurgists of that monarch thought to purify gold by adding to it only a 4 sth part of alloy, but we can easily suppose that the gold was found in this state of fineness.

If alloys were added to gold from a bad design, or with the mistaken idea of covering the expense of manufacturing it; this häs degenerated into fraud, and has ro limits : if the alloy was added with the view of making the money harder, it was a futile attempt. Neither of these motives could sway with Philip, because he enjoyed abundant mines of gold, and becauise, as he wished to appear generous, he would have made his coin of pure gold, if he thought it necessary to refine it : or he would have added more alloy; if policy suggested that he should not employ it as it came from the bowels of the earth*. It should seem, therefore; that his mines furnished him with gold at 23 carats and $a$ half $(0.979)$, as it is found to be in his coins, if there be no error in Patin's analysis : but it might perhaps be interesting to confirm this fact by a new experiment.

Chevalier Fossombroni, an emituent náthematician; in digging the foundation of a house near Arezzo, found a statera of Philip in good preservation, which he was kind enough immediately to give us to be examined by analysis:

On one side of this picce, as in riost of Philip's coins, there is a head of Apollo, and on the reverse a car with two horses: the name is on the exergue :-on similar coins we see under the legs of the horse a monogram or type indicating the mint where the coin was struck. On the piece in question there was a trident, which means Troezene.

Fourteen of these coitis are preserved in the cabinet of the Florence gallery : the face and the reverse of eleven of them are similar to that of Arezzo; but they have various distinguishing marks, one unly bearing the same mint-mark.

\footnotetext{
* I transmitted to M. Mongez the analysis of an ancient coin with the effigy of Philip: its examination also provid, that under the reign of that prince alloys were used in the making of morey, the composition of which was natural, or at least unknown; for it contained silver 368 , gold 184 , copper 448 .

It is not likely that so complex an alloy would have been used at a period when the modes of analysis were so little known, as to fall far short of the degree of exactness which may be attained even by employing the todtehstone and prepared acid now in use.
} 
with that found at Arezzo. The weight of two of these, completely similar in external appearance, was preciselv 176 grains of Florence cach. The same weight was found in another distinguished by a monogram formed by a large $K$, and a little $o$; the same weight in another which had a thunderbolı; the same in another with a vase; and lastly, in another with a grain of wheat, the mark of the Leontini. These six weights of the largest statera which remain, and which are equal, gave grounds for concluding that the above was the weight prescribed for the Greek money. This being granted, we may infer that the drachma weighed 88 grains. (Romé de l'Isle assigns three grains more to the great Attic drachma.) The proof of the accuracy of this calculation is to be found in the Athenian demidrachma, or Asiatic drachma, or the fourth part of the statera of Philip, which is preserved in the same gallery: this fragment weighs precisely $\mathbf{4} 4$ grains. The face of this small piece of gold presents the head of Hercules covered with a lion's skin, and on the reverse we see the bow, the vase, and club. M. Millin has communicated to me the weight of five stateræ preserved in the Imperial library, which are as follow : No.1. 160.5 grains; No.2. 161 grains precisely; No. 3. 161 grains; No.4. 162 grains precisely; No. 5. 162 grains. The two heaviest seem to be so from having been less worn. The largest would answer to $175^{\circ} 16$ grains of Florence, and would be lighter by gr. 0.84 than ours, which ought therefore to be regarded as less worn and more precise.

Mr. Greaves, in England, weigherd tw'o statera of Alexander, one of which was 133 English grains, and the other 133 and a half. He thought that the half-grain had been wasted by friction, and he concluded that the drachma ought to be reputed as being precisely at 67 grains. The second weight as given by Mr. Greaves would be equivalent to 87 grains and six-tenths of Florence. Suellius found the statera of Philip and of Alexander to weigh 179 Dutch grains, which makes 124 and a half English; and this, according to the furegoing comparison, would give to the drachma in Florence wcight 87 grains 0.9 ; all of them being a little lighter, but clusely approaching that which we had fixed at 88 grains.

Barthelemy, in France, found after various weighings that the drachma was precisely 81 French grains and an eighth : now, by the foregoing comparison, we ought to have for the drachma in Florence weight 87 grains and three-fourths. But this last author wishes to suppose a 
friction of se: en-eighths of a grain for 2,200 years wearing, and he gratnitously makes the drachma to be 82 whole French grains, which would make 88 and a half of Florence weight. It is best to banish entirely from our calculations all suppositions of friction, because, by admitting this to have been the case, we might draw a variety of vague conclusions. The weight of 88 grains which we have assigned to the gold drachma is confirmed by a silver one of this very Philip, also preserved in the Florence cabinet: this piece has on its face the head of Hercules without a beard, covered with a lion's skin; and on the reverse a Jupiter sitting, holding the cagle in his right hand and a spear in his left. It is distinguished from the others by a lyre, and the letter $\mathbf{A}$ under the seat. This drachma is also a proof of the exactness of its weight in its half, also in silver, of the same king, which weighs precisely 14 grains : on its face is the head of Jupiter with the diadem; on the reverse is a figure ou horseback, with the name on the exergue and a mark which is unintelligible. Besides, there are four pieces of four drachmas of Alexander of the same metal, the face and reverse of which are similar : all of these weigh 14 pennyweights and 16 grains, and prove completely that the weight of the drachma is 88 grains. These tetradrachmas are distinguished in the type by the addition of various signs, as we have said with respect to the stateræ: one has in front a lamp, and under the seat a moon and a star: another has in front the letter $\mathrm{T}$ with a circumflex accent, and under the seat the letter $\mathrm{E}$ : another has in front a buckler, and under the seat a serpent : the fourth has in front a crown, and under the scat a monogram composed of M. Finally, we have also a real drachma of this king of the precise weight of 88 grains, and which is distinguished by a monogran formed by an $H$, the cross bar of which has a kind of circumflex accent.

Among the tetradrachinas of Thrace there is one in the Florence collection, and the twelfth of the list, heavier than the rest; it weighs precisely 14 pennyweights and 16 grains: here we have a proof of the identity of the weights of the Thracians and Macedonians, as long ago supposed by the learned.

After the weighing of the Arezzo coin was finished, it was submitted to the cupel and to guartation. The standard was found to be the same with Patin's examination, i.e. 0.979 , or 23 carats and a half: it contained only half $\mathbf{a}$ carat, or 0.021 , of silver.

The art of assaying was known in the earliest times, as 


\section{Obscrvalions on the Purity of Standard Gold.}

attested by the Holy Scripture : we find it at such adegree of perfection even in the time of Pliny*, that by meaus of it the standard of gold was fixed at 21 carats, or 0.875 , at 21 carats and 7 -2thhs (0.883) up to 23 carats and $11-32$ ds $(0.973)$. In those days they must have assayed in the dry way, first by separating from the gold the viler metals by means of lead, anll afrerwards even the silver, with sulphur or with the sulphurets $\uparrow$.

They were also acquainted with the method of refining and purifying gold in large quanities, by cementing or burning it, as Strabo informs us, with an aluminous earth, which by destroying the silver left the gold in a state of purity. Pliny says that for this purpose they put the gold on the fire in an earthen vessel, with treble its weight of salt; that it was afterwards again exposed to the fire with two parts of salt and one of argillaceurs schistus: this would surely effect the decomposition of the salt, and the volatilization of the muriatic acid in a state of ignition and dry, which would penctrate the substance of the gold, and would separate the silver in the form of volatile muriate: this is the object of the process of cementation among the mo-

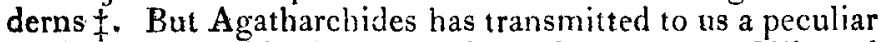
method practised in the mines situated between the Nile and the shores of the Red Sea, in which we recognise the wellknown property of the muriatic acid in the separation of silver.

This writer says (if we may trust to the text being accurate) that in these places gold is inclosed in marble; that the miners burn or calcine the ore; that they break it with

* The art of assayiug was certainly very imperfect at these periods: umder the emperors the standard of gold and sifver was still judged of by the colour assuried by the coin in the fire, and by the tint given to the touchstone on which the metil was rubbed.

These methods, alihough practised by cxpert workmen, could yield but very inaccurate results, which a variety of circumstances might influence; such as a complexity in the alloy, or a different alloy, \&c.

Archimedes would not have applied the laws of specific gravity to the determiation of the srandard value of king Hier's's crown, if he had known a better method.

We know also that under the triunvirate of Mtark Antony every street of Rome erected a massive statue to Marcus Gratianus, who had discovered and put in practice one of the processes of assaying mentioned above : this denotes the infancy of an useful art, the first steps of which were strongly encouraged as being intimatcly connccted with public happiness.

+ By employing the alkaline sulphurets, the solution of gold might have been effected: it is the metallic sulphurets, however, which ought to be used in this process.

+ M. de Robilant, in his detail of the processes of the mint at Turin, eays that cementation is the mode of refining generally adopted at Verice, Genoa, and at Florence, wliere they make gold sequins almost entirely pure. 
hammers, afterwards pound it, bruise it, and wash it; and finally, that the gold, when put into a close crucible, with a little lead, salt, a little tin, and barley meal, was exposed over the fire for five days.

The money-coiners of Darius certainly employed this method, or a similar one, when this enlightened king wished to give his subjects the noble and useful example of a mint made with the purest gold, similar to that of fine silver, which his satrap Ariander afterwards did.

To conclude:-lt is not easy to form an intelligible idea of the docimastic method, which Agatharchides has transmitted to us. But if in the operation which he describes there is no mention made of cementation, but of a true and prolonged fusion, it remains to explain how we can reconcile with the object in view, the employment of a close crucible held over the fire, as he describes : far less can we comprehend the use of the barley meal.

When we reflect, however, on the ingenious method described by Hellot as being practised at Lyons, in order to refine, purifv, and separate cupelled silver from the small quantity of lead which adheres to it after the first refining, we may perhaps comprehend what is meant*.

In Lyons they use crucibles thirteen inches high, and five broad at their orifice. About three inches deep of pounded charcoal is then put into the crucible and kept down by a lid, or rather a triangular piece of the crucible, which is kept in its place. On this lid or false bottom they put 60 or 65 pounds of long and thin ingots, in order to be melted and puritied. The wind furnace employed for this purpose is 14 inches high, seven in diameter at the grate, and nine at the top. The metal in melting was observed to fall three inches from the edges of the crucible: then, when it had acquired a sufficient degree of heat, it was seen to boil with the force and the agitation of water exposed to the heat of a strong fire; and in this state it was kept for seven or eight hours.

The elastic fluid, which in this case is extricated from the charcoal at the bottom of the crucible, produces the agitation above alluded to; and it forms, as it were, a kind

\footnotetext{
* It would be necessary, hefore deciding finally on the process detailed by Agatharchides and that which is practised at Lyons, to repeat them, taking the greatest care to apply the modern methods of chemical analysis, and above all the pneumato-chemical apparatus: it would be necessary to determine the nature of the gas, which passes through the melted silver, and ascertain why the gas is forned under a certain pressure, and why it does not pass out through the pores of the crucible. The experiment of $M$. Fabbroni does not seem to me to be conclusive.
} 
of bellows ingeniously placed at the bottom of the crucible.

We know that charcoal, when put into close vessels of metal or glass, is not altered, although it becomes red. Theory dictates this, and several experiments confirm it. But the observation of the fact related by the judicious Hellot also proves, that in this case the charcoal below the melted silver is decomposed, and continually furnishes elastic fluid; since this excellent chemist found that silver kept over a similar fire, without charcoal being placed below it, undulated at the surface, going from the centre to the edges, and vice versa ; but that in fact it does not bubble with so much noise: from whence then does the elastic fluid originate in this case?

Priestley, the founder of the modern pneumatic chemistry, demonstrates in the plainest manner, what has been since confirmed by several other experiments, that earthen vessels heated until they armit light to pass through them, are filters, or rather sieves, which allow even the external air to enter; that caloric and light penetrate by the bottom of the crucible, and with them air, attracted chemically by the charcoal which is inside: its oxygen coming in contact with the charcoal, which is in a state of incandescence, inflames a portion of it, is combined with itself and with the caloric, forming carbonic acid, an elastic fluid, which, by the uninterrupted action of the fire, augments and acquires a sufficient elasticity to overcome the pressure of a column of seven inches of liquid silver, which is above, and passes through it agitating it violently. The small residue of lead, which is united with and diffused over the mass, being put by a continual agitation in contact with the carbonic acid gas, and with the atmosphere (the latter and perhaps the former are decomposed by a greater affinity under certain circumstances), is oxidated, and by the diminution of specific gravity is constrained to occupy the upper surface.

In fact, Hellot saw a kind of yellowisti oil rise from the inside of the silver which floated on the top of the crucible: this oil was a pure oxide of lead melted and formed by the contact of the atmospheric air, which is continually renewed. The refiners collect this melted oxide by absorbing it with glass or with sour earth; this earth being most easily removed from off the silver which it covers, and the metal then remains limpid and pure.

On comparing this method with the process of Agatharchides, reported here so imperfectly, we may suppose that 
the barley, or the barley meal, was used instead of charcoal, in order to form what the Lyonnese call the soul of the crucible, which was placed at the bottom of it, where it was retained by a covering (from which probably comes the expression of closed crucible), on which the gold in fusion was placed by means of a little lead (in order to vitrify the base metals which it might contain,) and some common salt, sulphuret of antimony or of lead, in order that they may lay hold of the fine silver and volatilize it with the lead, or reduce it to scoriz. The elastic fluids, extricated from the vegetable matter by the action of the fire, form the office of bellows for incessantly agitating the metal during several days, which makes all the impurities swim above, and which ought to be skimmed off as the Lyonnese do.

Properly speaking, a fire which lasts five days gives rather an idea of the cementation of the moderns, and analogous to that which Pliny has communicated to us, than a real fusion in close crucibles, - a circumstance which would be directly contrary to the object in view. Thus, in Hungary, in order the better to open all the interior parts of the gold to the muriatic acid reduced into vapour in the cementation, they are accustomed to add lead to the mass, which is afterwards reduced into small hollow drops, or, in other words, into grains. It may be that the lead indicated by Agatharchides has the same object: the tin may have been taken by an equivoque for crude antimony, for galenum, or for the native sulphuret of lead: it is possible likewise that the barley meal was merely intended to serve for the equal distribution of the little salt, a stratum of which must be placed on the gold, and perhaps assisted to decompose it, as argil or sulphate of iron now does.

In order to obtain some light upon this curious subject, there were put into a crucible covered by another crucible turned upside down, thirty pennyweights of barley-meal, and an ounce of common salt : it was then made red-hot, and kept 36 hours in this state. There was put in, more for the sake of curiosity than any thing else, a thin piece of gold weighing 24 grains, and a piece of silver weighing 40 grains. The lower crucible was half full, and an opening was left at the joining of the two crucibles to let out the elastic vapour.

After this space of time, the apparatus being cooled was opened, and there was found a small earthy residue slightly saline and whitish, weighing eleven grains and a half. The gold was above; it was increased one-eighth of a grain in 
weight, because it was evidently whitened by the fusion of very minute particles of silver delached from the smalf fragment of silver, which was then found adhering immediately over the gold, in the form of agglutinated dust: this fragment of silver weighed six grains and one-eighth. We afterwards boiled this gold (which was silvered only on its surface) for some time in pure nitric acid; when it lost completely its silver colour; and when assayed it was found to be 24 carats.

We proceeded afterwards to examine the sniall earthy residue, in which we found, in saline particles; only a few atoms of muriate of soda, and scarce a trace of muriate of copper. The muriate of silver, which, on account of the loss suffered by the piece of silver; ought to have formed $a$ weight of 45 grains and a half, was certainly evaporated with the other elastic vapours. Eleven grains and a half only of muriatic acid concurred in the formation of this muriate: the thirteen pennyweights and a half of tre same acid, which besides contained the common salts employed in this experiment, have therefore been dissipated (by not paying attention to the little copper) by a decomposition effected by means of the vegetable matter which was joined with it : but what is difficult to account for, and which is foreign to our object, is the evaporation of ten whole pennyweights of soda; contained in the common salt, and which ought to have remained fixed at the bottom of the vessel : it had therefore become volatile, either by decomposition, or by a new composition, and it had escaped by the aperture in the apparatus.

It is not probable, therefore, that Philip made use of similar methods of refining, either by flux or by cementation, because, we repeat, he would have redueed the gold to a state of perfect purity, as Darius wished to do subsequently; or he would not have limited himself to so small a portion of alloy, or perhaps this alloy would not have been silver. And if he employed gold in the state in which he found it, we must be forced to admit that nature furnished it at 23 carats and $a$ half fine, or of the standard of $(0 \cdot 979 *)$.

Many

* Reaumur says (Mémoires de l' Académie des Sciences 1718, p. 87,) that the gold brought from the bed of the river Ceze is at the standard of $18^{\circ}$ carats eight grains.

$\begin{array}{ccccc}\text { Guld of the Rhone } & . & . & \ldots & 20 \text { carats. } \\ \begin{array}{c}\text { of the Rhine } \\ \text { of the Arriege }\end{array} & \ldots & \ldots & . . & 214 \\ \end{array}$

Reaumur also observes, that the standard varies in the same piece of nas- 
Many persons will probably doubt that gold is found in fature so near a state of perfect purity, although Strabo intimates that perfectly pure gold was found in the Alps, and Pliny is cited as asserting that no silver was ever found in it. But without remaining in suspense with respect to the assertions and opinions of others, I am enabled from my own experiments to remove all uncertainty, having ascertained that native gold is 24 carats (1000).

I had for some time the charge of the fine collection of natural history belonging to our sovereign, who was fond of that science. His majesty possessed many specimens of mineralized gold and native gold, among which I remarked two well formed crystals of gold, viz. one cubical, the other prismatic with four faces, surmounterl by a pyramid with four faces also. It would be interesting to know what substances united to the gold have determined these various figures formed naturally in the bowels of the earth, and which are totally different from those which are produced in the laboratories of the chemist after melted gold is cooled. The cube is very pale, the prism is higher coloured; but these two crystals, which I found by chance, (when choosing among several natural grains,) are unique in this depôt; so that it would be improper to subject them to an examination which would alter their form. An unshapen specimen, but at the same time a remarkable one, from the Brazils, enriches this collection. The weight of this piece is about fourteen pounds; and I examined a bit of it by the cupel and by quartation, without omitting also to examine its solution in the nitro-muriatio acid, with the sulphate of iron, and with neutral salts with a base of potash. I have been convinced by all these operations, that this was pure gold of 24 carats without any alloy of inferior netal.

From all that I can learn, therefore, it appears that gold is found in a native state in various degrees of purity, and to prove this has been the object of the present dissertation.

tive gold. M. Deluc informs us that the gold found at Wicklow in Ireland was alloyed with a ninth part of its weiglit in silver.

M. Fabbroni is the first who has demonstrated that native gold is found in a state of purity: this is a most important observation; but it does not seem to destroy the idea that native gold is a natural alloy ol gold and silver: a principle established by a great number of facts, and to which we as yet know but one exception.

If would be interesting to ascertain whether lead is present in ancient coins or medals: this would be the surest method of determining whether the jucients refined their gold, or employed it as nature presented it.

XXIII, An 